\title{
Climate change in Ireland- recent trends in temperature and precipitation
}

\author{
Laura McElwain and John Sweeney \\ Department of Geography, National University of Ireland, Maynooth
}

\begin{abstract}
This paper presents an assessment of indicators of climate change in Ireland over the past century. Trends are examined in order to determine the magnitude and direction of ongoing climate change. Although detection of a trend is difficult due to the influence of the North Atlantic Ocean, it is concluded that Irish climate is following similar trajectories to those predicted by global climate models. Climatic variables investigated included the key temperature and precipitation data series from the Irish synoptic station network. Analysis of the Irish mean temperature records indicates an increase similar to global trends, particularly with reference to early-twentieth century warming and, more importantly, rapid warming in the 1990s. Similarly, analysis of precipitation change support the findings of the United Kingdom Climate Impacts Programme (UKCIPS) with evidence of a trend towards winter increases in the north-west of the country and summer decreases in the south-east. Secondary climate indicators such as frequency of 'hot' and 'cold' days were found to reveal more variable trends.
\end{abstract}

Key index words: climate change, trends, precipitation, trajectories.

\section{Introduction}

An increase in global surface temperature of $0.6 \pm 0.2^{\circ} \mathrm{C}$ has occurred since the latenineteenth century (IPCC, 2001). Most of this warming has occurred during two main periods: $1910-1945$ and 1976 to the present. During the present episode of rapid warming, temperatures have increased at a rate of $0.15^{\circ} \mathrm{C}$ per decade (Jones et al., 2001). The 1990s were the warmest decade in the series which extended from 1856 to 2000 , with the eight warmest years globally having occurred since the 1990s (Palutikof, 2001). The bulk of this warming has occurred at night. Daily minimum air temperatures over land have increased at twice the rate of daily maximum temperatures since 1950 . There has also been a reduction in the frequency of low temperatures, with a smaller increase of extreme high temperatures (IPCC, 2001). Because of this, the freeze-free season in many mid/high latitude regions has lengthened. There have also been related increases in cloud cover, at the rate of 2 percent during the twentieth century, especially over mid/high latitudes (IPCC, 2001).

Increases in precipitation, of $0.5-1$ percent per decade in the $\mathrm{mid} / \mathrm{high}$ latitudes of the Northern Hemisphere, have also been observed over the course of the twentieth century (IPCC, 2001). This would again appear to be related to increases in cloud amount. Analysis of the frequency of heavy rainfall events indicates a probability of over 90 percent that a 2-4 percent increase in frequency has occurred during the past 50 years in the Northern Hemisphere (IPCC, 2001).

This paper presents an analysis of the long-term variation of mean annual surface air temperature and total annual precipitation for a number of stations in Ireland. Figure 1 outlines the location of the fourteen synoptic stations operated by Met Eireann, along with the location of Armagh observatory which was also used in this study. Daily maximum and minimum temperatures for eight synoptic stations are also examined in order to detect Irish Geography, Volume 36(2), 2003, 97-111. 
possible local and regional trends. The daily frequencies of unusually high and low temperatures are assessed, using threshold temperatures of $18^{\circ} \mathrm{C}$ and $0^{\circ} \mathrm{C}$. Changes in daily rainfall are also described for the same period. Kendall's non-parametric rank correlation test is used to assess statistical significance, which is enhanced with a least squares linear regression model to determine the magnitude of the trend. To investigate the relationship between large-scale phenomena such as the North Atlantic Oscillation (NAO) and seasonal temperature and precipitation, a simple correlation method is used.

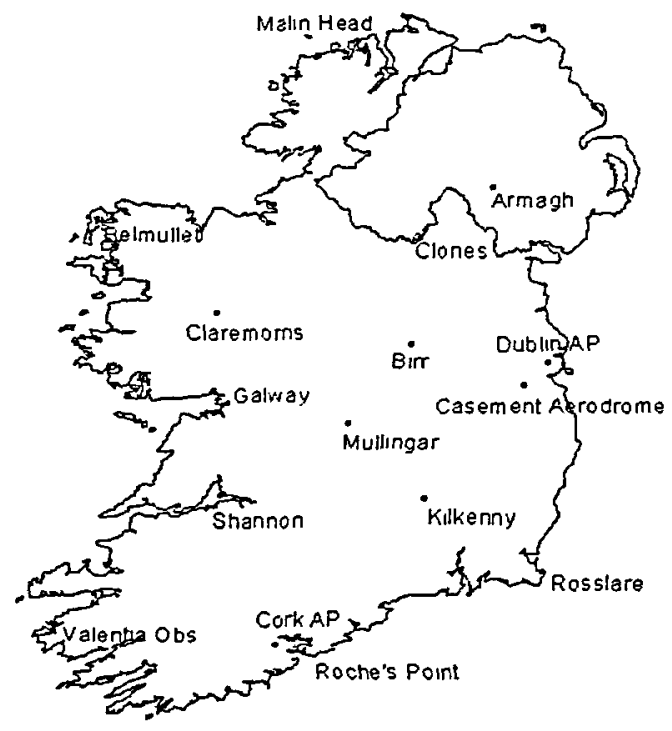

Figure 1: Location of synoptic weather stations in Ireland.

\section{Irish Temperature Record}

The increase in global temperature identified by the IPCC may or may not have been matched by a comparable trend in Ireland. To examine this, it is necessary to conduct studies on a local and regional scale. Monthly data were aggregated and annual averages produced for each of four long-term stations in Ireland: Birr, Valentia, Malin Head and Armagh from 1890-2000. An air temperature anomaly was then calculated using the 1961-90 period as a baseline. This approach was similar to that employed by researchers at the Climate Research Unit at East Anglia in the UK in deriving the global surface air temperature anomaly. Both time series are shown in Figure 2.

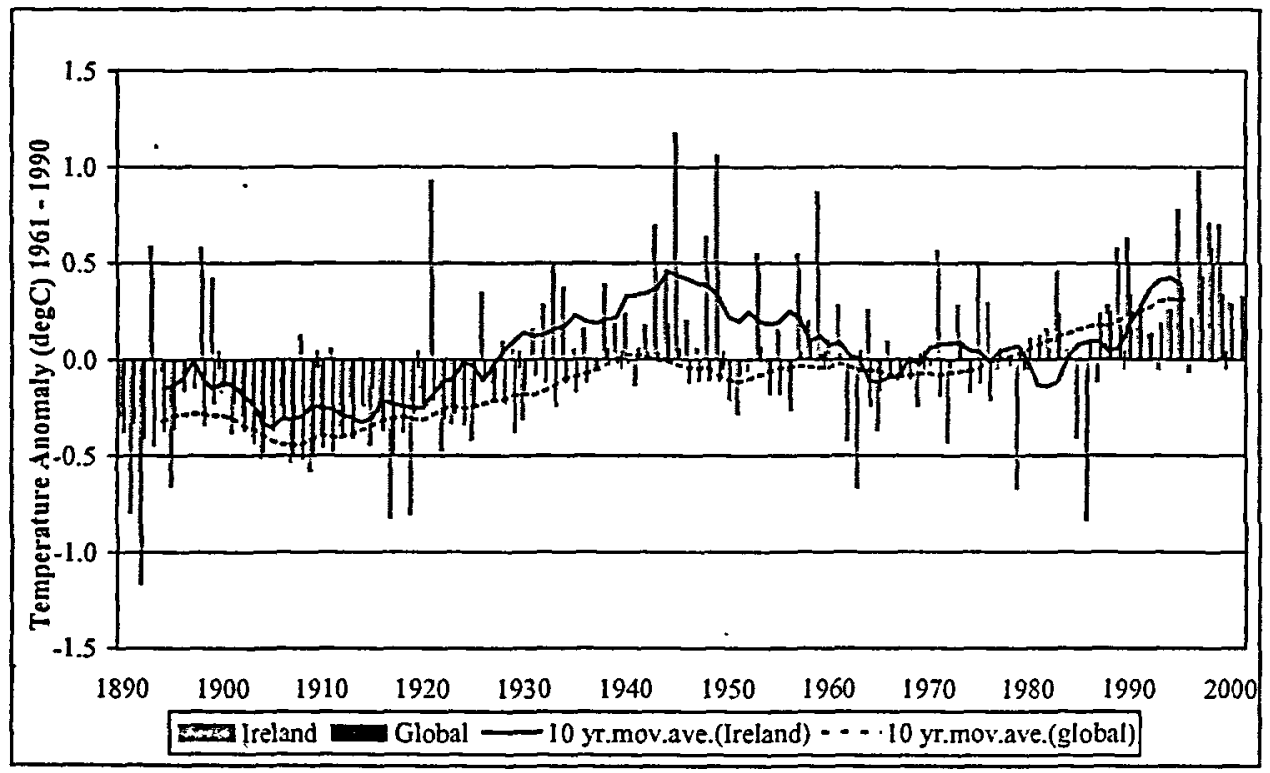

Figure 2: Global and Irish air temperature anomalies, $1890-2000$. 
An increasing global temperature trend is apparent from 1910 to 1940 , followed by. a slight decrease until the mid-1970s. Since then global average temperatures have consistently exceeded the 1961-1990 average. Ireland, however, exhibits much greater interannual variability, with departures of over $1^{\circ} \mathrm{C}$ from the mean. Nevertheless, Ireland reveals a similar trend to the global one, with the warming not occurring as a linear process but in two distinct and separate phases. First, an initial long period of warming occurred between 1920 and 1950 with the warmest year of the twentieth century in Ireland being 1945. Secondly, a short cool phase lasting until the mid/late 1970s took place. Finally, a period of abrupt and highly significant warming was recorded from the mid-1970s to the present. Irish temperatures show a moderate but significant warming for the whole period, of approximately $0.5^{\circ} \mathrm{C}$, in agreement with results obtained at the global scale $\left(0.6^{\circ} \mathrm{C}\right)$. However, in the past two decades, it is apparent more rapid warming has taken place in Ireland than globally. Five of the ten warmest years in the Irish instrumental record have occurred since 1990, with 1997 being the warmest year of the decade, compared to 1998 which was the warmest year of the entire instrumental record globally. This is in agreement with UK trends, where the 1990 s have been the warmest decade in records extending over 240 years (Hulme and Jenkins, 1998). The tendency for Irish temperatures to generally lag somewhat behind the global trend may be due to the buffering effect of the North Atlantic Ocean. A more detailed analysis of temperature records for the past 50 years from the synoptic station network showed consistency with this long-term air temperature record.

Emerging evidence for an anthropogenically-induced warming signal adds urgency to the importance of monitoring maximum and minimum temperature, as well as the mean (Folland et al., 1999). One of the expectations from greenhouse warming is a somewhat greater increase in minimum relative to maximum temperature (Folland et al., 1999). Some researchers have found an asymmetrical diurnal warming, with an increase in daily minimum temperatures at a rate nearly twice that of maximum temperatures since approximately 1950 (IPCC, 2001). Not all regions show greater warming at night, although it is the dominant signal in many regions (Jones, 2001). Jones et al., (1999) in their analysis of the Central England Temperature record found an increase in temperature which corresponds to a reduced number of days with temperatures much below normal. An increase in days with temperatures much above normal however was not so evident.

A least squares linear regression line was fitted to maximum and minimum temperature data for each of eight synoptic stations for each season to establish a generalised trend over the period of record, 1960 to 2000 . An identical period of record from each station was considered in order to enable direct comparability to be achieved. It is evident that minimum temperatures are warming more than maximum temperatures in spring, summer and autumn, with maximum temperatures in winter warming more than minimum temperatures. The only evidence of decreasing seasonal temperatures is in spring, summer and autumn minimum temperatures at Dublin Airport. At most stations, trends in summer minimum and winter maximum temperatures are significant at the $95 \%$ level or greater. This can be seen in Table 1 .

At a global level, the greatest seasonal warming has occurred during the Northern Hemisphere winter and spring, and as a result, the difference between summer and winter temperatures has decreased (IPCC, 2001). It may be concluded that, in Ireland, it is the winter warming which contributes most to the recent warming trend in Irish climate, with winter maximum temperatures accounting for most of this. The greatest warming occurs in the period November to March, with the least warming in April, May, June, September and October. 
Table 1: Increase/ decrease in maximum and minimum temperatures ( ${ }^{\circ}$ Celsius) by season for 8 synoptic stations, $1960-2000$.

\begin{tabular}{|c|c|c|c|c|c|c|c|c|}
\hline & $\begin{array}{l}\text { Spring } \\
\text { Max }\end{array}$ & $\begin{array}{l}\text { Spring } \\
\text { Min }\end{array}$ & $\begin{array}{l}\text { Summer } \\
\operatorname{Max}\end{array}$ & $\begin{array}{l}\text { Summer } \\
\text { Min }\end{array}$ & $\begin{array}{l}\text { Autumn } \\
\operatorname{Max}\end{array}$ & $\begin{array}{l}\text { Autumn } \\
\text { Min }\end{array}$ & $\begin{array}{l}\text { Winter } \\
\text { Max }\end{array}$ & $\begin{array}{l}\text { Winter } \\
\text { Min }\end{array}$ \\
\hline Valentia & +0.36 & +0.77 & +0.62 & $+1.16^{* *}$ & +0.36 & +0.72 & $+1.01 *$ & $+1.28^{*}$ \\
\hline Shannon & $+0.87^{*}$ & $+1.66^{* *}$ & $+1.22 *$ & $+1.85 * *$ & +0.69 & $+1.36^{* *}$ & $+1.39^{* *}$ & $+1.86^{* *}$ \\
\hline Dublin & $+1.03^{* *}$ & -0.18 & $+1.17 *$ & -0.04 & +0.46 & -0.27 & $+1.40^{*}$ & +0.46 \\
\hline Malin Head & +0.25 & +0.73 & +0.39 & $+0.89^{* *}$ & +0.34 & +0.57 & $+0.99^{*}$ & +0.75 \\
\hline Belmullet & $+0.84^{*}$ & +0.84 & $+1.20 * *$ & $*+1.32^{* *}$ & $+0.82^{*}$ & +0.42 & $+1.25^{* *}$ & +1.12 \\
\hline Birr & +0.69 & +0.79 & +0.97 & $+1.14^{* *}$ & +0.45 & +0.60 & $+1.34^{*}$ & +1.15 \\
\hline Kilkenny & $+0.96^{*}$ & $+1.00^{*}$ & $+1.23^{*}$ & $+1.34^{* *}$ & +0.67 & $+1.21^{*}$ & $+1.46^{* *}$ & $+1.22 *$ \\
\hline Mullingar & +0.11 & +0.74 & +0.12 & $+0.81^{* *}$ & +0.25 & +0.27 & $+1.42^{*}$ & +1.09 \\
\hline
\end{tabular}

\section{Secondary temperature indices}

In some investigations, important information regarding climate change detection is lost when monthly or longer averages are used (Przybylak, 2000). More revealing trends, however, may be identified by analysing daily data and changes in the frequency of days above and below certain thresholds. A relatively small change in mean can lead to large changes in the frequency of extremes (Katz and Brown, 1992; Salinger and Griffiths, 2001). Globally, there has been a trend towards reduced numbers of frost and cold days and an increase in the number of hot days during the past century (Karl et al., 1999). Ireland's oceanic climate means that temperature extremes are rare, however, and, as a result, the mean air temperature fluctuates within quite narrow limits. Maximum temperatures above $30^{\circ} \mathrm{C}$ have a once in a century return period at coastal locations and once every 50 years inland. Temperatures less than $-7^{\circ} \mathrm{C}$ occur approximately every second year inland, while only approximately once every 100 years at Valentia (Sweeney, 1997). Because of this, standard indices as defined by the climate change detection working group and established by the WMO (World Meteorological Organisation) and CLIVAR (Climate Variability and Predictability) cannot be used. A study on the Central England Temperature (CET) has defined a 'hot' day as a day when the mean temperature is greater than $20^{\circ} \mathrm{C}$ (Hulme, 1999a). For the purposes of this study a 'hot' day is defined as any day when the mean temperature is greater than $18^{\circ} \mathrm{C}$, whereas a 'cold' day is defined as any day when the mean temperature is less than $0^{\circ} \mathrm{C}$.

The frequency of hot and cold days is currently quite low on the northern and western seaboards, but inland and on the east coast there can be significant occurrences. At Birr (Figure 3), Dublin Airport (Figure 4) and Kilkenny (Figure 5) the number of hot days have increased. This increase has been significant at Dublin Airport and Kilkenny at the $95 \%$ significance level. Cold days for the three stations have decreased significantly - at the $99 \%$ level for Birr, at the $95 \%$ level for Kilkenny and at the $90 \%$ level for Dublin. Birr and Kilkenny only had seven hot and seven cold days per year on average (1961-1990) but Kilkenny experienced 34 hot days and Birr 32 hot days in 1995. Also, in 1998, Kilkenny had no cold days and Birr only had two. Dublin Airport, while not experiencing as many hot or cold days on average (six and four respectively), has also had recent years with up to nineteen 
hot days (1995) and a number of years with only one or two cold days (1993, 1994, 1996, 1997, 1998). These findings are similar to those found in Hulme's study on the Central England Temperature Record (Hulme, 1999a) which showed an increase in recent years in the number of summers with temperatures above $20^{\circ} \mathrm{C}$, although no long-term trend in the number of cold days.
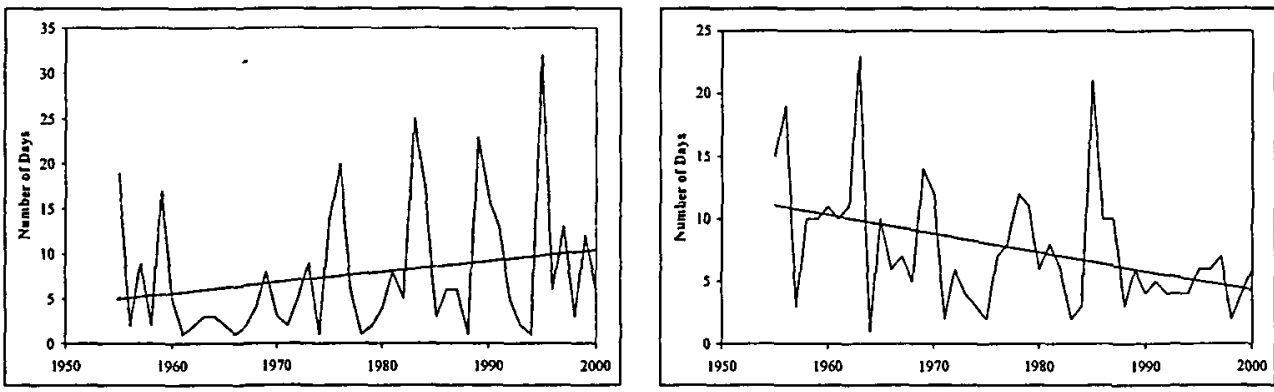

Figure 3: Frequency of 'hot' and 'cold' days per year at Birr.
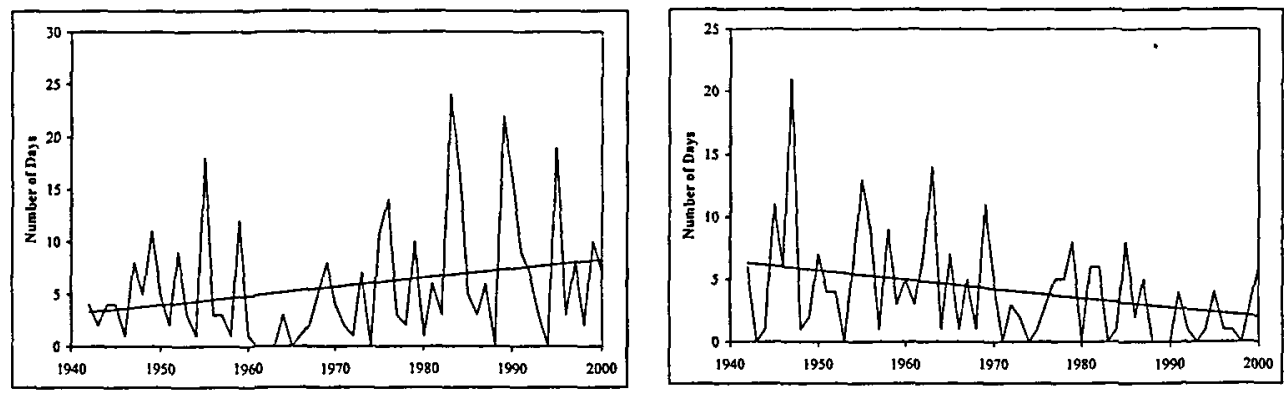

Figure 4: Frequency of 'hot' and 'cold'days per year at Dublin Airport.
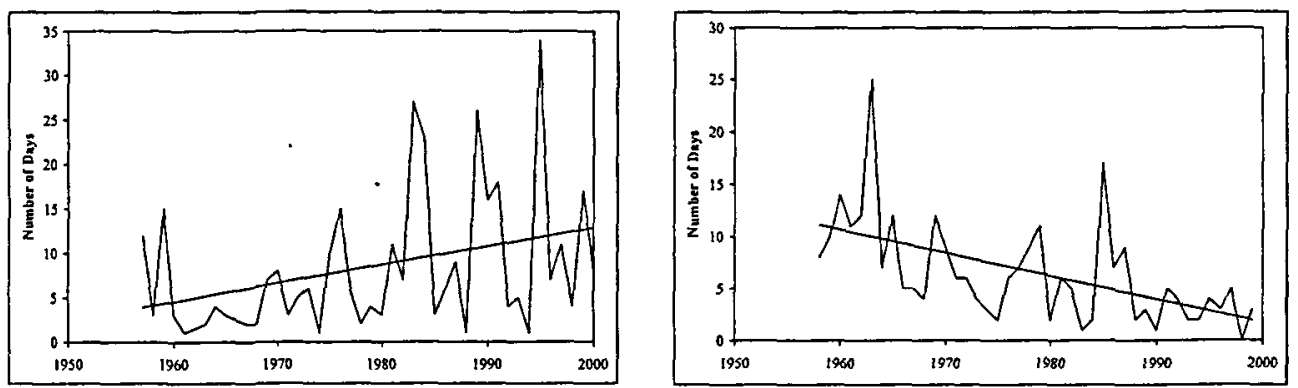

Figure 5: Frequency of 'hot' and 'cold' days per year at Kilkenny.

Due to an increase in minimum temperatures in spring and autumn, it might be expected that the length of the frost season would shorten, with a reduced number of frost days annually. In the north-eastern United States, Cooter and LeDuc (1995) found that the start of the frost-free season occurs eleven days earlier now than in the 1950s (Easterling et al., 2000). The season in Ireland is measured when minimum temperatures fall below $0^{\circ} \mathrm{C}$ (Keane, 1986). At Birr and Malin Head, the frost season appears to be shorter in recent years due primarily to an earlier last frost (Figure 6). At Birr the last frost has shifted from the first week in May to the last week of April, while at Malin Head, the last frost is over 2 weeks earlier, changing from mid March to the beginning of the month. Valentia and Dublin Airport, on the 
Birr
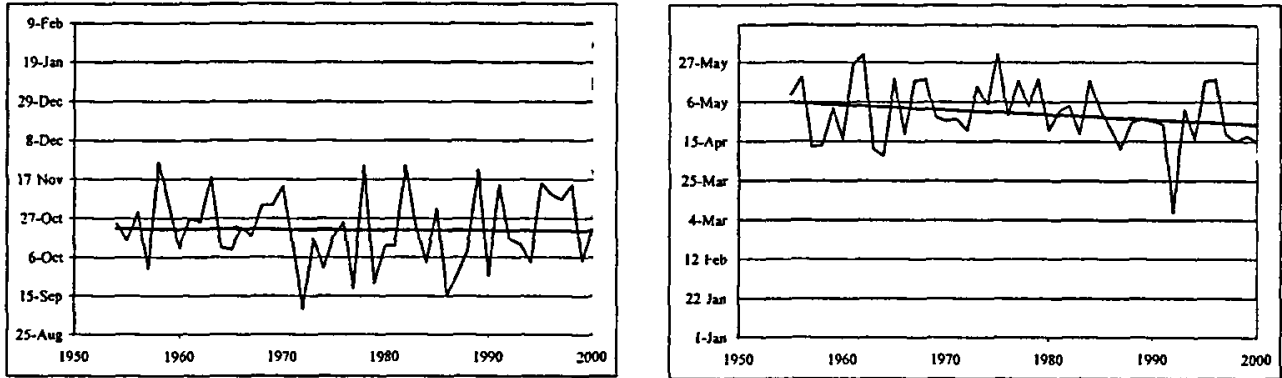

Malin Head
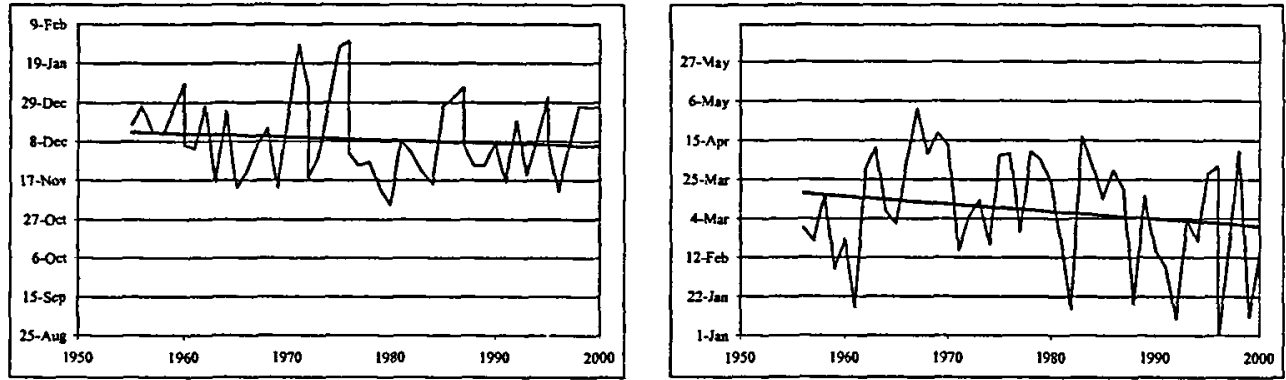

Dublin Airport
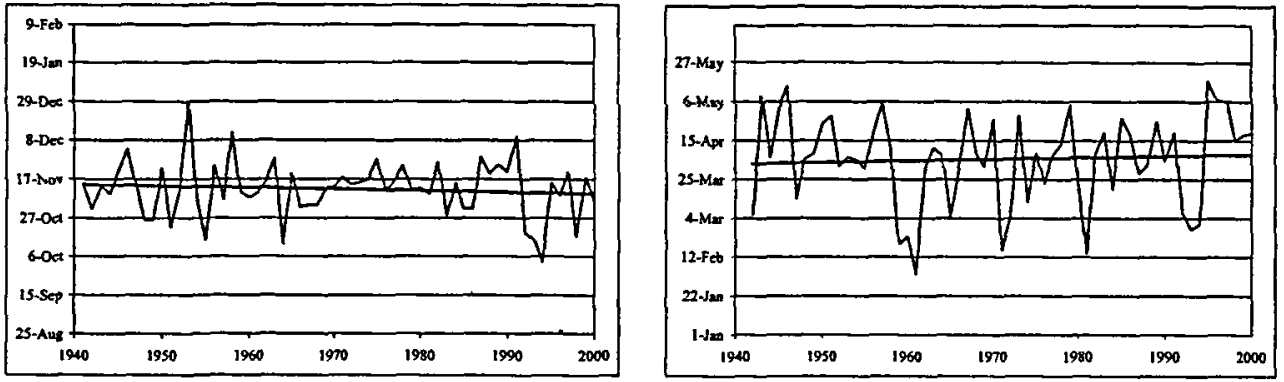

Valentia
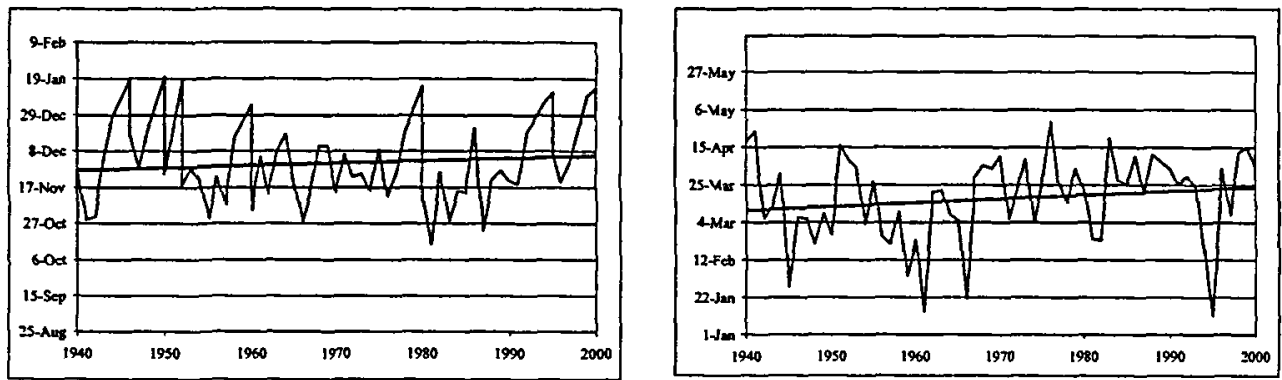

Figure 6: Date of first and last frost at Birr, Malin Head, Dublin Airport and Valentia. 


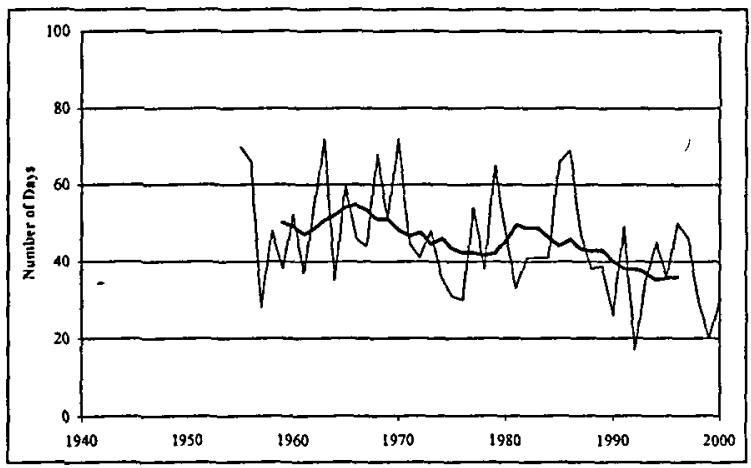

Birr

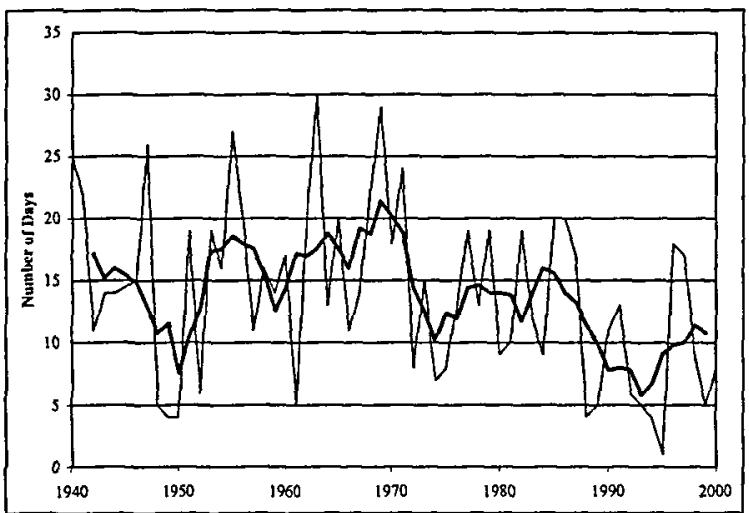

Valentia

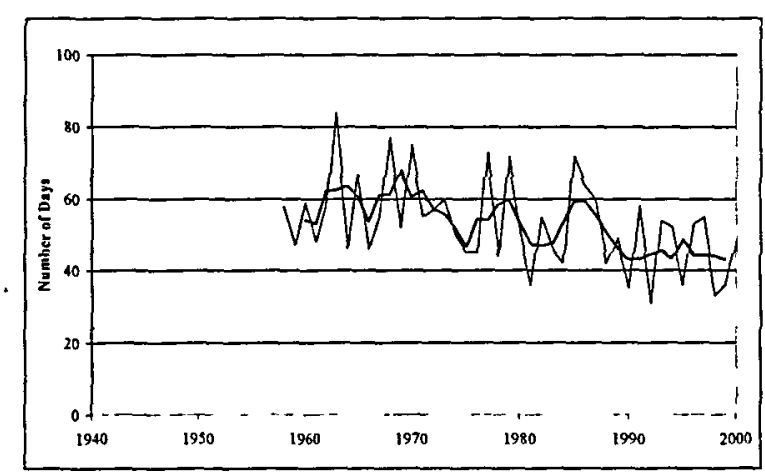

Kilkenny

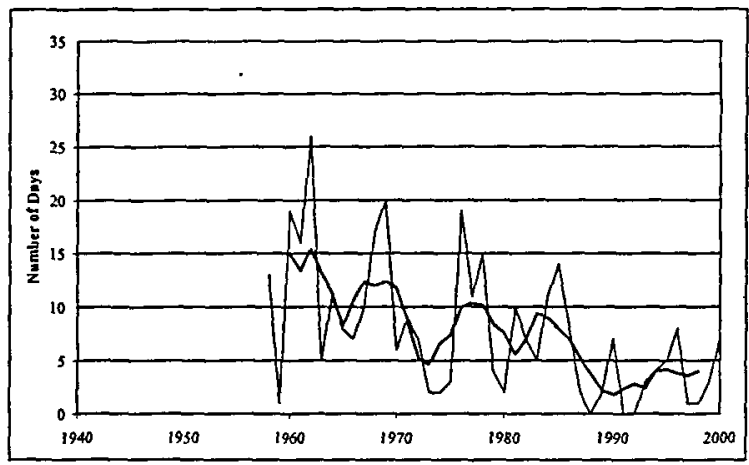

Rosslare

Figure 7: Number of frost days per year at Birr, Valentia, Kilkenny and Rosslare, with 5-year moving average. 
other hand, have a slightly longer frost season than in the past. At Valentia, the last frost is nine to ten days later, shifting from the second week in March to the last week in March, and at Dublin Airport the first frost is approximately four days earlier and the last frost four days later. Unfortunately, it is difficult to determine real and significant trends due to wide year-toyear variations. Clearly this indicator would have important consequences for farmers, especially those growing frost-sensitive crops.

Perhaps a better indicator than the length of frost season may be the frequency of days within each season experiencing a frost, defined as a day with a minimum temperature less than $0^{\circ} \mathrm{C}$. In both Australia and New Zealand, the frequency of days below freezing decreased in association with a warming in daily minimum temperatures, which also appeared to be related to changes in atmospheric circulation in the region (Plummer et al., 1999). This trend is also apparent in Europe, as evidence exists that the decrease in number of frost days since the 1930s appears to be associated with strong increases in winter minimum temperatures (Heino et al., 1999).

The number of air frosts on the south and north-west coast of Ireland is only about ten per year (Rohan, 1986). Moving inland, the number of days with frost increases rapidly and there can be 50-60 days with air frosts per year in the midlands. At four stations in Ireland, two coastal and two inland, there are significant decreases (at a level greater than $95 \%$ ) in the frequency of frost days (Figure 7). Birr has the greatest decrease, with a reduction of approximately fourteen days since 1955 , significant at the $95 \%$ level. Kilkenny, Valentia and Rosslare also display significant decreases, from a reduction of seven days at Valentia since 1940 , to eleven at Kilkenny and Rosslare, since 1958. Again this would be related to the decline in 'cold' days and the general increase in seasonal minimum temperatures.

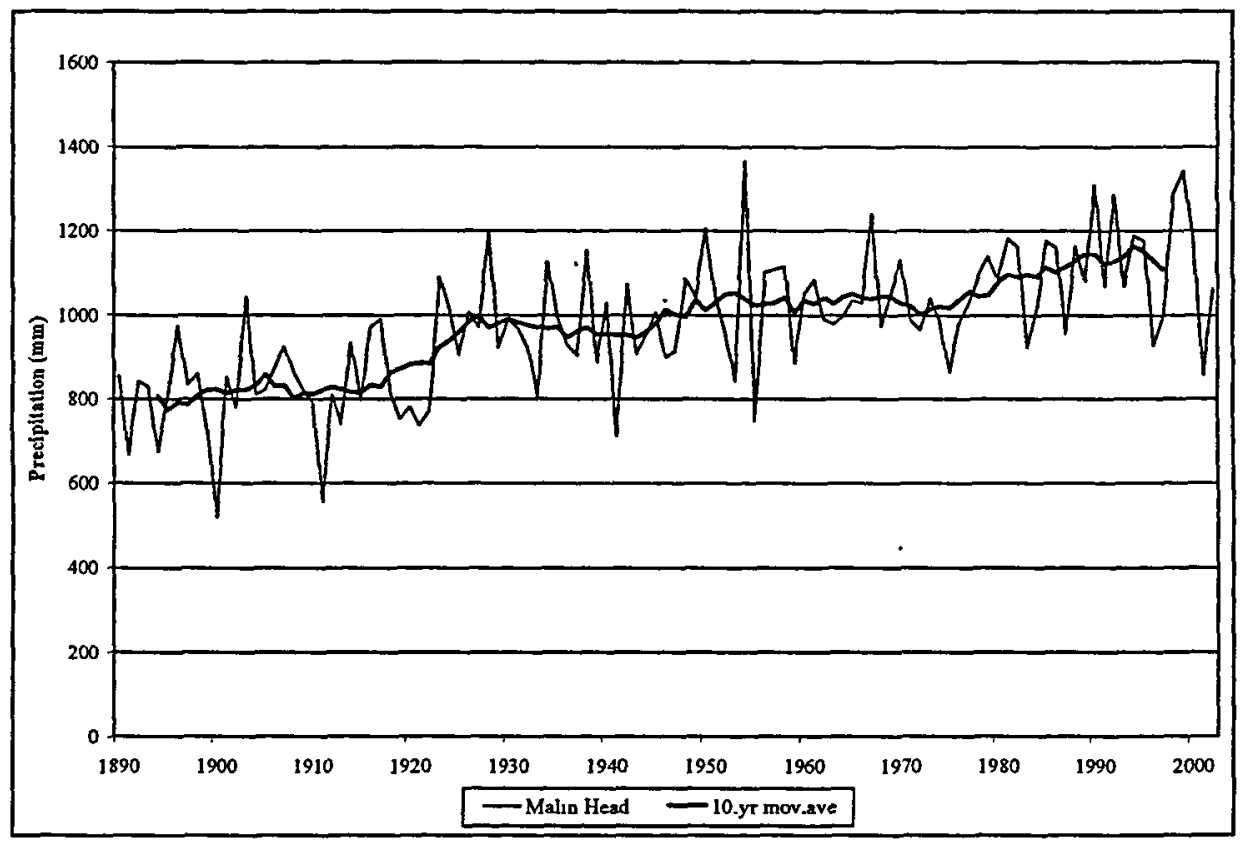

Figure 8: Total annual precipitation at Malin Head (thin line), 1890-2000, with 10-year moving average (thick line). 
The necessity for looking at extremes on a global basis has been highlighted by Folland et al. (1999), as these indicators can be quite important for policy and decision-makers. In response to global warming and increases in mean temperature, it may be expected that there will be a continued increase in hot days and a corresponding decrease in the frequency of cold days in the future. Obviously this would also have serious implications for a variety of sectors, including agriculture and water resources.

\section{Irish precipitation record}

Analyses of yearly and seasonal precipitation trends indicate a small positive global trend in precipitation over land during the twentieth century (IPCC, 2001). These also show that the pattern is not homogenous, as large areas are characterised by negative trends. Any warming of the lower atmosphere will inevitably cause changes in precipitation due to an altered hydrological cycle. This may have more important impacts on human and environmental systems than any change in temperature. Trends in European annual precipitation reveal increases in rainfall in northern Europe of between 10 and 40 percent during the twentieth century, while there has been little change or drying in southern Europe (Parry, 2000). Furthermore, climate modelling studies suggest more pronounced precipitation gradients from north-west to south-east in Britain and Ireland for the future (Hulme, 1999b). The general pattern for future precipitation changes is for wetter winters and wetter summers in northern Europe, and drier summers in southern Europe (Parry, 2000).

Irish rainfall trends appear to be consistent with these suggested patterns. Total annual precipitation has increased in the north of the country, at Malin Head, with slight decreases in the south of the country, at Roche's Point and Rosslare. At Malin Head there has been a significant increase of over $350 \mathrm{~mm}$ since 1890 and this can be seen clearly in Figure 8 . This is accounted for mainly by significant increases in winter rainfall, although summer rainfall in the north has also been increasing. Four out of five of the wettest years experienced at Malin Head have occurred in the $1990 \mathrm{~s}$, when annual rainfall totals have been above $1150 \mathrm{~mm}$ per year.

In this analysis, at Birr in the midlands, there was no clear trend, although there was a decrease in rainfall during the 1960s. This was followed by an increase and levelling off again in annual totals. In the south-east, at Roche's Point and Rosslare, there has been a slight decrease, from $1100 \mathrm{~mm}$ to $950 \mathrm{~mm}$ approximately (ten-year moving average). At both Birr and Roche's Point (Rosslare was used after the automation of Roche's Point) decreased summer precipitation is the main driver of the annual trend. Neither Birr nor Roche's Point/Rosslare trends are statistically significant, however.

Analyses of seasonal variations in precipitation in Ireland reveal that the autumn and winter seasons show the greatest increases. Recent years have seen some of the most intense events, with 1998 being the wettest year in the synoptic records for the whole country, and the winter of 1994/95 being the wettest winter. Monthly records reveal that February, March and October were the wettest months and appear to be getting wetter, while May, August and September tend to be the driest. Kiely (1999) also found that March and October are the months with the largest increase in precipitation, particularly on the west coast of Ireland.

Variations in precipitation can be caused by a change in the frequency of precipitation events, changes in the intensity of precipitation per event, or a combination of both. Globally, there is evidence of increases in the intensity of extreme rainfall events in some regions, but 

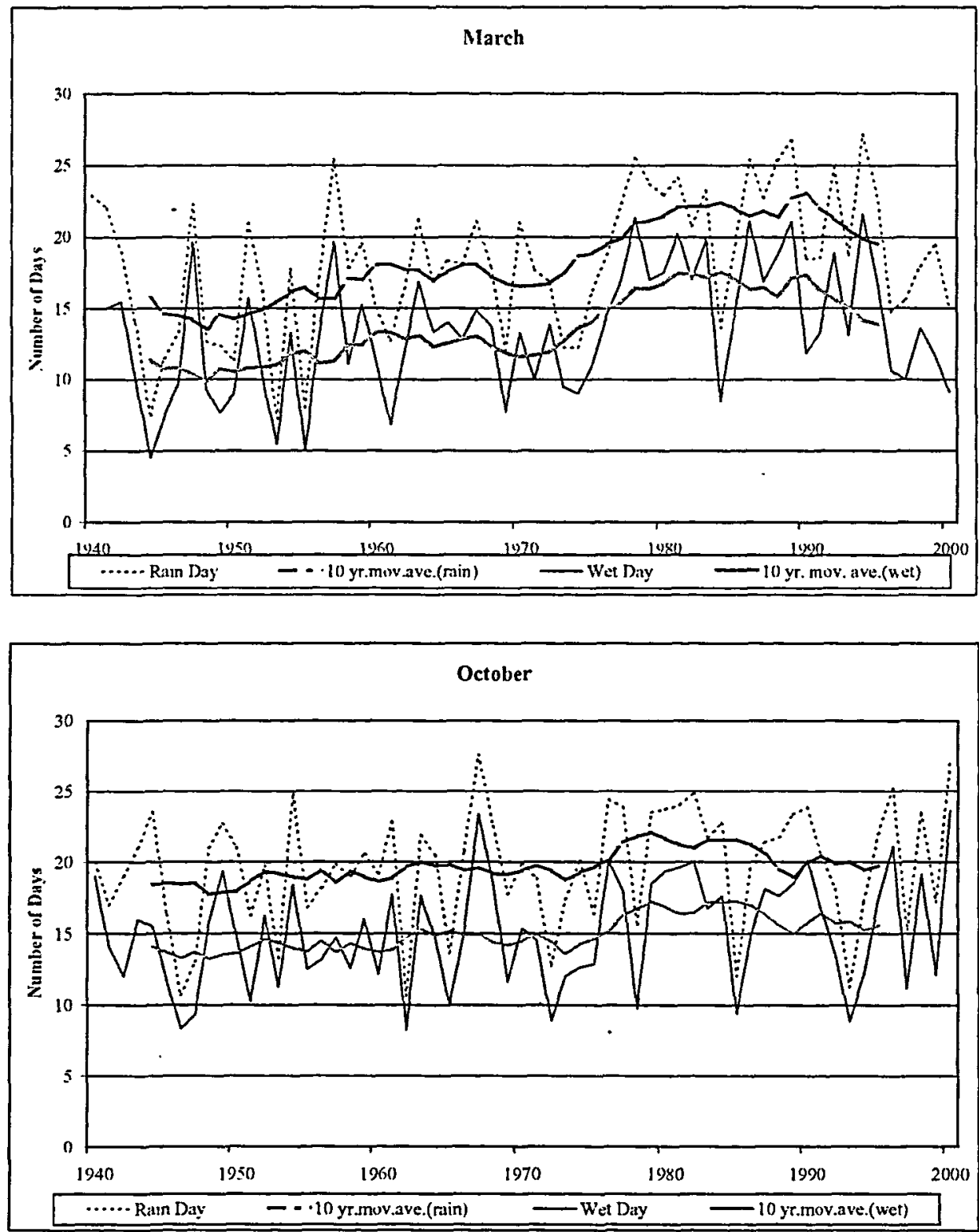

Figure 9: Frequency of rain and wet days in (a) March and (b) October, averaged for eight synoptic

$$
\text { . } \quad \text { stations. }
$$

no clear large-scale pattern has emerged. In analysing the frequency of rainfall events in Ireland, thresholds were selected according to standard definitions used by the World Meteorological Organisation. A rain day is defined as a day with at least $0.2 \mathrm{~mm}$ of precipitation, while a wet day is a day with greater than or equal to $1.0 \mathrm{~mm}$ (Rohan, 1986). Figure 9 shows the results for an average of eight synoptic stations. March and October are the months which reveal most positive trends. Linear trends indicate increases of six and five rain and wet days respectively for March, and increases of three rain and three wet days in 
October. There has been a general increase in wet and rain days from January to April and in October and November, with decreases in the May to September period and in December. However, only the March trends are significant. Changes in the intensity of precipitation on these wet and rain days were also examined. This showed wide variations both spatially and temporally. The greatest daily rainfall at any of the synoptic stations was at Valentia on $1^{\text {st }}$ November 1980 when $116 \mathrm{~mm}$ was recorded. Sheridan (2001) in his selection of rainfall stations reported monthly totals increasing in March, April and October, with decreases in May, July, August and September. These trends are further confirmed with a large number of significant positive trends in March rain and wet days, and negative trends in September rain and wet days. However, large local differences and the small number of stations analysed makes this an ambiguous indicator and, as such, it is difficult to ascertain whether these changes are indeed the result of long-term climatic changes. Nevertheless, studies in other countries on rainfall intensities have found that countries which experience a significant increase or decrease in monthly and seasonal precipitation have found this change to be related directly to a change in the same sign in heavy and extreme events (Easterling et al., 2000).

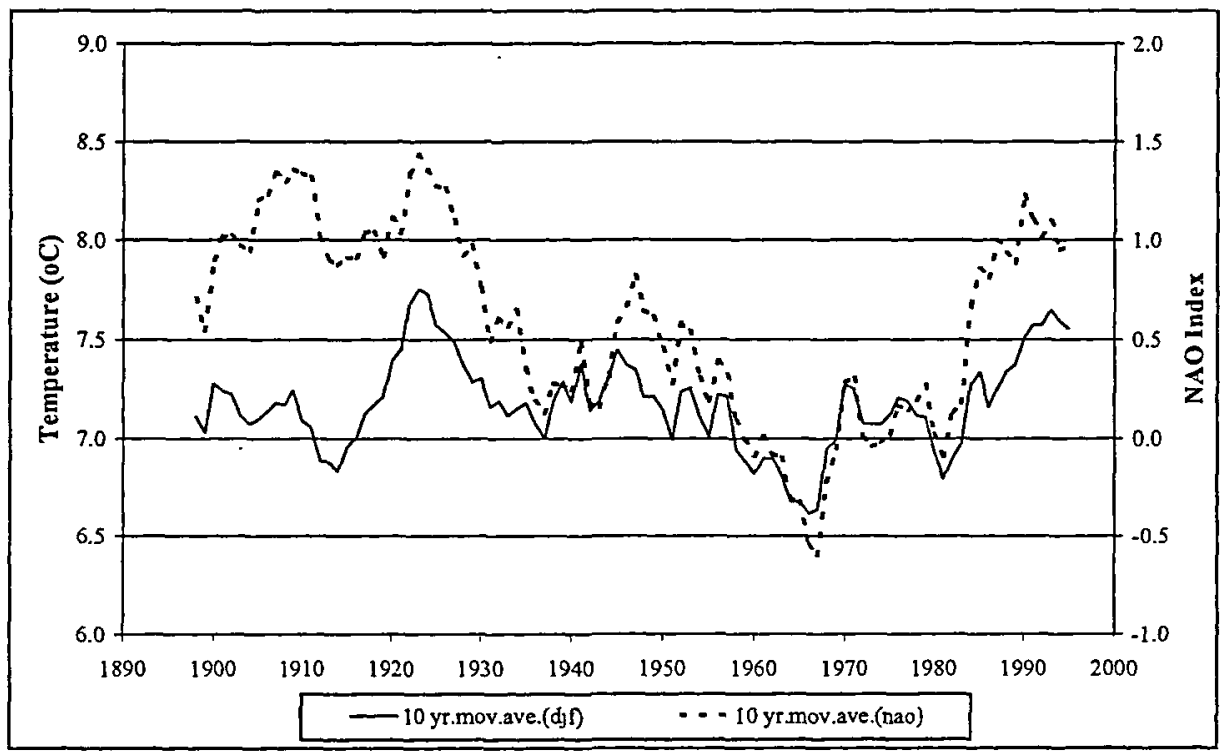

Figure 10: Valentia winter temperatures in relation to the North Atlantic Oscillation Index.

\section{Relationship with circulation indices}

In order to understand why the changes outlined above have occurred it is necessary to consider the atmospheric dynamics and the physical processes operating (Trenberth, 1990). This section briefly examines the relationship between atmospheric circulation and temperature and precipitation at selected sites on the west coast of Ireland. An index of circulation frequently cited in studies on northern European climate variability is the North Atlantic Oscillation (NAO). This is a mode of natural variability most prevalent during the winter months when pressure gradients are at their strongest. When sea level pressure is lower than normal near Iceland, and/or higher then normal near the Azores, the NAO is said to be 


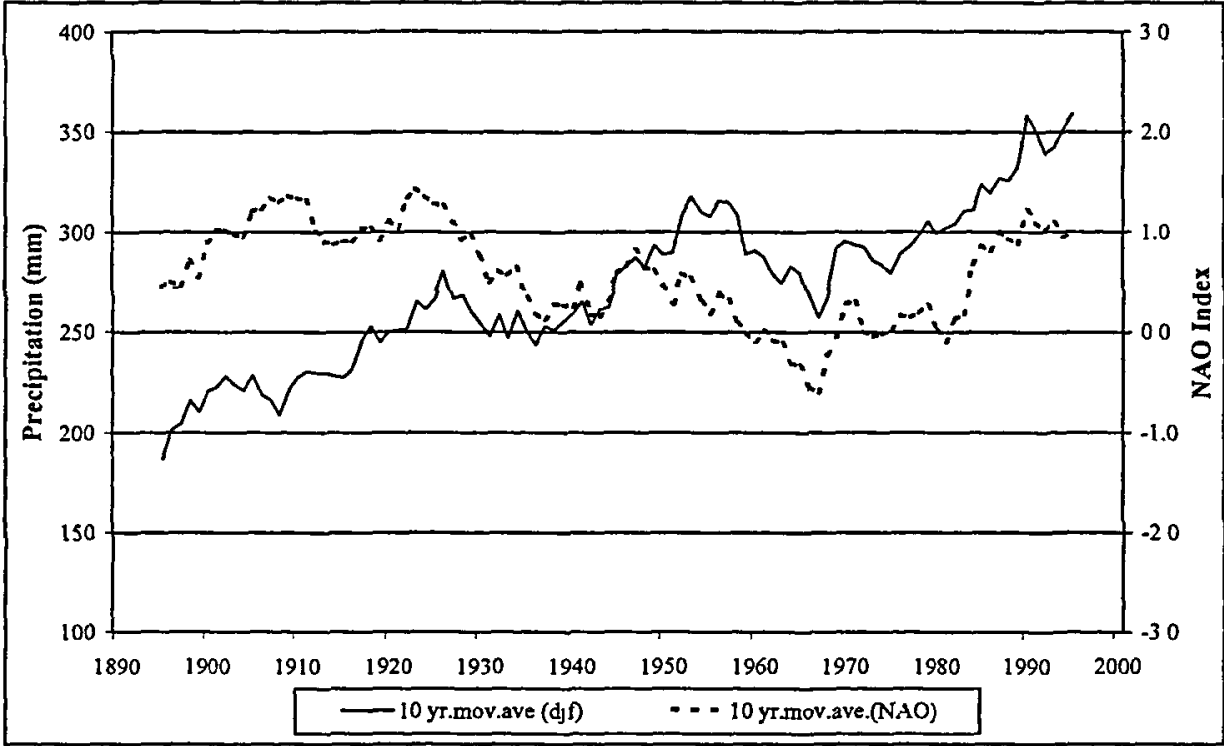

Figure 11: Malin Head winter precipitation in relation to the North Atlantic Oscillation Index.

in a positive phase, and in a negative phase if the opposite occurs. When the NAO is in a positive phase, the storm tracks moving across the North Atlantic Ocean are stronger, bringing depressions north-eastward into Northern Europe. This mode is also associated with an increase in wind speed from the west and an increase in temperature and precipitation for Northern Europe. The wintertime NAO exhibits significant interannual and interdecadal variability (Hurrell, 1995). The index was in a markedly positive phase at the beginning of the century and has been again since the mid-1970s. The index has been calculated since the middle of the nineteenth century and is updated at the Climate Research Unit at the University of East Anglia.

Correlations between the winter phase of the NAO and winter maximum, minimum and mean temperatures at Malin Head and Valentia reveal positive correlations, significant at the 99\% level. Malin Head and Valentia have been chosen as they represent the longest surface climate record for the west coast of Ireland (since 1890). As the NAO is also a measure of the strength of the westerlies, Wilby et al., (1997) found significant positive correlations between the Central England Temperature and the Lamb westerly weather type. According to Hurrell (1996) the NAO explains about 30 percent of the variance of mean winter Northern Hemisphere temperatures. In Ireland, the variation in temperature (1890-2000) explained by the NAO is approximately 30 percent and 50 percent for Malin Head and Valentia respectively. Figure 10 outlines the relationship between the winter phase of the NAO and winter temperatures at Valentia. There is a clear agreement between the time series with positive values of the NAO being associated with higher winter temperatures, and negative phases of the NAO with lower temperatures.

Above normal winter precipitation occurs in northern Europe when the NAO is in a positive phase, while the opposite occurs when in a negative phase. In relation to Irish precipitation, again there is a significant correlation, at the $99 \%$ level, between winter precipitation and the winter phase of the NAO. Figure 11 shows Malin Head winter 
precipitation in relation to the winter NAO index. As with temperature, positive values of the $\mathrm{NAO}$ are associated with higher precipitation values, while negative NAO phases are linked with lower precipitation.

It is evident that the NAO explains a substantial portion of the variance in temperature and precipitation on the west coast of Ireland in winter. Obviously there will be other modes of atmospheric circulation variability which play an important role in the climate of Ireland during other seasons and at other locations. Future research will study spatial and temporal differences, at both the surface and aloft, of atmospheric circulation so as to provide a better understanding of the mechanisms that are influencing the weather conditions in Ireland.

\section{Conclusion}

This research has been a first-step exploratory analysis to determine whether long-term changes in Irish temperature and precipitation have occurred, and if so, what has been the magnitude of this change. A temperature increase of $0.5^{\circ} \mathrm{C}$ has been observed over the course of the twentieth century. This trend has been similar to the global trend with warming occurring in two distinct phases, most apparent in the 1990s. Recent warming would appear to have been most pronounced during the night (daily minimum) as opposed to the day (daily maximum) for the summer and autumn seasons. Overall, warming has been strongest in the winter season, as daytime temperatures have increased to a greater extent. There have also been considerable and significant decreases in the frequency of frost and cold days at a number of stations, and an associated increase in occurrence of hot days.

Precipitation indicators for Ireland also appear to confirm global climate model predictions with winter increases in the north-west of the country and summer decreases in the south-easi. Given the limited number of sites investigated, only preliminary conclusions can be drawn conceming spatial and temporal precipitation trends. However, significant increases have been detected in the frequency of March rain and wet days for eight synoptic stations analysed. This provides corroboration for the findings of Sheridan (2001). Such changes in rainfall climatology, should they be accompanied by changes in extreme events, may have widespread implications, especially for flood hazard and water resource managers, planners and engineers.

Preliminary investigations have identified significant relationships between precipitation and temperature and the North Atlantic Oscillation Index in winter on the west coast of Ireland. The future course of Irish climate is undoubtedly going to be linked with large-scale atmospheric circulation and it is important to realise that monitoring changes in climatic elements has to be accompanied by monitoring of changes in other atmospheric circulation indices.

\section{Acknowledgements}

The work reported in this paper was undertaken as part of an EPA-funded project on Climate Change Indicators for Ireland, Contract no 2000-LS-5-MI-5.2.2. The authors also wish to acknowledge the assistance of the Climatology Division, Met Eireann, and the Climate Research Unit, University of East Anglia for the provision of data. 


\section{References}

COOTER, E. and LeDUC, S. (1995) Recent frost dates in the northeastern United States, International Journal of Climatology, 15, 65-75.

EASTERLING, D.R., HORTON, B., JONES, P.D., PETERSON, T.C., KARL, T.R., PARKER, D.E., SALINGER, M.J., RAZUVAYEZ, V., PLUMMER, N., JAMASON, P. and FOLLAND, C.K. (1997) Maximum and minimum temperature trends for the globe, Science, 277, 364-367.

EASTERLING D.R., EVANS, J.L., GROISMAN, P.Ya., KARL, T.R., KUNKEL, K.E. and AMBENJE, P. (2000) Observed variability and trends in extreme climate events: a brief review, Bulletin of the American Meteorological Society, 81, 417-425.

FOLLAND, C.K., MILLER, C., BADER, D., CROWE, M., JONES, P., PLUMMER, N., RICHMAN, M., PARKER, D.E., ROGERS, J. and SCHOLEFIELD, P. (1999) Workshop on indices and indicators for climate extremes, Asheville, NC, USA, 3-6 June 1997. Breakout group C: Temperature indices for climate extremes, Climatic Change, 42, 31-43.

FRICH, P., ALEXANDER, L.V., DELLA-MARTA, P., GLEASON, B., HAYLOCK, M., KLEIN TANK, A. and PETERSON, T. (2002) Observed coherent changes in climatic extremes during the second half of the twentieth century, Climate Research, 19, 193-212.

HEINO, R., BRAZDIL, R., FORLAND, E., TUOMENVIRTA, H., ALEXANDERSSON, H., BENISTON, M., PFISTER, C., REBETEZ, M., ROSENHAGEN, G., ROSNER, G and WIBIG, J. (1999) Progress in the study of climatic extremes in North and Central Europe, In: Karl, T.R., Nicholls, N. \& Ghazi, A. (eds) Weather and Climate Extremes: changes, variations and a perspective from the insurance industry. The Netherlands: Kluwer Academic Publications.

HORCAS, R., RASILLA, D. \& FERNANDEZ-GARCIA, F. (2001) Temperature variations and trends in the Segura River Basin: An exploratory analysis, In: Brunet India, M. \& Lopez Bonillo, D. (eds) Detecting and modelling regional climate change. Berlin: Springer-Verlag.

HULME, M. (1999a) Air temperature in Central England, In: Cannell, M.GR., Palutikof, J.P. and Sparks, T.H. (eds) Indicators of climate change in the UK. UK: Centre for Ecology and Hydrology.

HULME, M. (1999b) Precipitation gradient across the UK, In: Cannell, M.G.R., Palutikof, J.P. and Sparks, T.H. (eds) Indicators of climate change in the UK. UK: Centre for Ecology and Hydrology.

HULME, M. and JENKINS, GJ. (1998) Climate change scenarios for the UK: scientific report. UKCIP Technical Report No. 1. Climate Research Unit, East Anglia, Norwich.

HURRELL, J.W. (1995) Decadal trends in the North Atlantic Oscillation: regional temperatures and precipitation, Science, 269, 676-679.

HURRELL, J.W. (1996) Influence of variations in extratropical wintertime teleconnections on Northern Hemisphere temperature, Geophysical Research Letters, 23, 665-658

IPCC (2001) Climate change 2001: The scientific basis. [Houghton, J.T., Ding, Y., Griggs, D., Noguet, M., van der Linden, P., Dai, X., Maskell, K., Johnson, CA. (eds)]. Cambridge: Cambridge University Press.

JONES, P.J. (2001) Instrumental temperature change in the context of the last 1000 years, In: Brunet India, M. and Lopez Bonillo, D. (eds) Detecting and modelling regional climate change. Berlin: Springer-Verlag.

JONES, P.D., HORTON, E. B., FOLLAND, C.K., HULME, M., PARKER, D.E. and BASNETT, T.A. (1999) The use of indices to identify changes in climate extremes, In: Karl, T.R., Nicholls, N. and Ghazi, A. (eds) Weather and climate extremes: changes, variations \& a perspective from the insurance industry. The Netherlands: Kluwer Academic Publications.

KARL, T.R., NICHOLLS, N. and GHAZI, A. (1999) CLIVAR/GCOS/WMO Workshop on Indices and Indicators for Climate Extremes, Climatic Change, 42, 3-7.

KATZ, R.W. and BROWN, B.G. (1992) Extreme events in a changing climate: Variability is more important than averages, Climatic Change, 21, 289-302.

KEANE, T. (1986) Climate, Weather and Irish Agriculture. Dublin: Agmet.

KIELY, G (1999) Climate change in Ireland from precipitation and streamflow observations, Advances in Water Resources, 23, 141-151. 
PALUTIKOF, J.P. (2001) Global temperature record: Information sheet. Accessed on-line. www.cru.uea.ac.uk.

PALUTIKOF, J.P., SUBAK, S. and AGNEW, M.D. (1997) Economic Impacts of the Hot Summer and the Unusually Warm Year of 1995. London: Department of the Environment.

PARRY, M.L. (2000) Assessment of potential effects and adaptations for climate change in Europe: The Europe Acacia Report. UK: Jackson Environment Institute, University of East Anglia.

PLUMMER, N., SALINGER, J.M., NICHOLLS, N., SUPPIAH, R., HENNESSY, K.J., LEIGHTON, R.M., TREWIN, B., PAGE, C.M. and LOUGH, J.M. (1999) Changes in climate extremes over the Australian region and New Zealand during the twentieth century, Climatic Change, 42, 183-202.

PRZYBYLAK, R. (2000) Diurnal temperature range in the Arctic and its relation to Hemispheric and arctic circulation patterns, International Journal of Climatology, 20, 231-253.

ROHAN, P.K. (1986) The climate of Ireland. Dublin: Stationery Office.

SALINGER, M.J. and GRIFFITHS, GM. (2001) Trends in New Zealand daily temperatures and rainfall extremes, International Journal of Climatology, 21, 1437-1452.

SHERIDAN, T. (2001) Analysis of trends at some Irish rainfall stations. Technical Report 59/2001. Dublin: Met Éireann.

SWEENEY, J. (1997) Ireland, In: Wheeler, D. \& Mayes, J. (eds) Regional Climates of the British Isles. London: Routledge.

TRENBERTH, K.E. (1990) Recent observed interdecadal climate changes in the Northem Hemisphere, Bulletin American Meteorological Society, 71, (7), 988-993.

WILBY, R.L., O'HARE, G and BARNSLEY, N. (1997) The NAO and British Isles climate variability, 1865-1996, Weather, 52, 266-275. 